\title{
Neurosteroid Modulation of GABA IPSCs Is Phosphorylation Dependent
}

\author{
András Fáncsik, ${ }^{1}$ David M. Linn, ${ }^{1}$ and Jeffrey G. Tasker ${ }^{1,2}$ \\ ${ }^{1}$ Department of Cell and Molecular Biology and ${ }^{2}$ Neuroscience Program, Tulane University, New Orleans, \\ Louisiana 70118-5698
}

The neurosteroid $3 \alpha$-hydroxy-5 $\alpha$-pregnan-20-one (allopregnanolone) facilitates $\mathrm{GABA}_{\mathrm{A}}$ receptor-mediated ionic currents via allosteric modulation of the $\mathrm{GABA}_{\mathrm{A}}$ receptor. Accordingly, allopregnanolone caused an increase in the slow decay time constant of spontaneous GABA-mediated IPSCs in magnocellular neurons recorded in hypothalamic slices. The allopregnanolone effect on IPSCs was inhibited by a G-protein antagonist as well as by blocking protein kinase $\mathrm{C}$ and, to a lesser extent, cAMP-dependent protein kinase activities. G-protein and protein kinase $\mathrm{C}$ activation in the absence of the neuroste-

Neuronal function is acutely modulated by a class of steroids, the neurosteroids, that are synthesized de novo in the CNS (Corpechot et al., 1993; Cheney et al., 1995; Schumacher and Baulieu, 1995). 3 $\alpha$-Hydroxy-5 $\alpha$-pregnan-20-one (Allopregnanolone), a progesterone metabolite, has been shown to enhance the $\mathrm{GABA}_{\mathrm{A}}$ receptor-mediated $\mathrm{Cl}^{-}$current caused by exogenously applied GABA (Majewska et al., 1986; Harrison et al., 1987; Lambert et al., 1990; Puia et al., 1993; Rupprecht et al., 1993). The modulatory efficacy of the neurosteroids seems to depend on the subunit composition of the $\mathrm{GABA}_{\mathrm{A}}$ receptor. Variations in subunit subtypes change or eliminate completely the neurosteroids' ability to modulate GABA currents (Shingai et al., 1991; Zaman et al., 1992; Puia et al., 1993; Zhu et al., 1996; Maitra and Reynolds, 1998, 1999; Smith et al., 1998; Brussaard et al., 1999). Receptor phosphorylation seems to play a role in the regulation and modulation of the $\mathrm{GABA}_{\mathrm{A}}$ receptor complex. Several studies have demonstrated that $\mathrm{GABA}_{\mathrm{A}}$ receptor function is regulated by phosphorylation via $\mathrm{Ca}^{2+}$ /phospholipid-dependent protein kinase C (PKC) (Krishek et al., 1994; Poisbeau et al., 1999), cAMP-dependent protein kinase (PKA) (Poisbeau et al., 1999), $\mathrm{Ca}^{2+} /$ calmodulin-dependent protein kinase II (McDonald and Moss, 1994), and protein tyrosine kinase (Bureau and Laschet, 1995; Moss et al., 1995; Dunne et al., 1998) and by an unidentified kinase associated with the $\mathrm{GABA}_{\mathrm{A}}$ receptor (Bureau and Laschet, 1995). Similarly, there is preliminary evidence that phosphorylation plays a role in the modulation of the $\mathrm{GABA}_{\mathrm{A}}$ recep-

Received Sept. 28, 1999; revised Jan. 31, 2000; accepted Feb. 17, 2000.

This research was supported by National Institute of Mental Health Fellowship Grant 1 F32 MH 12422-01, National Institute of Neurological Disorders and Stroke Grant NS 31187, the Tulane/Xavier Center for Bioenvironmental Research, and Department of Energy Grant DE-FG21-93EW-53023. We thank Kriszta Szabó and Katalin Halmos for their technical support and Dr. Ken Muneoka for his invaluable comments regarding second messenger-signaling mechanisms.

Correspondence should be addressed to Dr. Jeffrey Tasker, Department of Cell and Molecular Biology, 2000 Percival Stern Hall, Tulane University, New Orleans, LA 70118-5698. E-mail: tasker@mailhost.tcs.tulane.edu.

Copyright (C) 2000 Society for Neuroscience $0270-6474 / 00 / 203067-09 \$ 15.00 / 0$ roid had no effect on spontaneous IPSCs but enhanced the effect of subsequent allopregnanolone application. These findings together suggest that the neurosteroid modulation of GABA-mediated IPSCs requires G-protein and protein kinase activation, although not via a separate G-protein-coupled steroid receptor.

Key words: hypothalamus; neurosteroid; progestin; allopregnanolone; kinase; phosphorylation; $G A B A_{A}$ receptor; G-proteins; whole-cell recording

tor complex by neurosteroids (Gyenes et al., 1994; Leidenheimer and Chapell, 1997).

Neurosteroid levels measured in the CNS and in the blood are correlated with different reproductive endocrine states (Corpechot et al., 1993, 1997; Heesch and Rogers, 1995; Palumbo et al., 1995; Bixo et al., 1997). Changes in the hypothalamic allopregnanolone level during the estrus cycle seem to serve a functionspecific modulatory role because they are not accompanied by changes in other brain regions (e.g., cortex) (Genazzani et al., 1995). The oxytocin- and vasopressin-producing magnocellular neurons of the hypothalamic supraoptic nucleus (SON) are sensitive to several neurosteroids (Patchev et al., 1996; Poisbeau et al., 1997; Richardson and Wakerley, 1998), including allopregnanolone (Purdy et al., 1991; Dayanithi and Tapia-Arancibia, 1996), which has been shown to potentiate GABA-mediated IPSCs (Brussaard et al., 1997). During parturition and lactation, the sensitivity of magnocellular neurons to allopregnanolone decreases (Brussaard et al., 1999), which correlates with underlying changes in the subunit composition of the $\mathrm{GABA}_{\mathrm{A}}$ receptor complex (Fenelon and Herbison, 1996; Brussaard et al., 1997).

Although much is known about the modulatory effects of neurosteroids on GABA-mediated currents, very little is known about the underlying molecular mechanisms of neurosteroid modulation of $\mathrm{GABA}_{\mathrm{A}}$ receptors. We used whole-cell patchclamp recordings in rat hypothalamic slices to study the G-protein and protein kinase dependence of the allopregnanolone effect on spontaneous $\mathrm{GABA}_{\mathrm{A}}$ receptor-mediated IPSCs in magnocellular neurons of the SON. On the basis of our findings, we propose that phosphorylation of the $\mathrm{GABA}_{\mathrm{A}}$ receptor is required for the allosteric enhancement of synaptic GABA currents by neurosteroids.

\section{MATERIALS AND METHODS}

Slice preparation. Male Sprague Dawley rats (40-120 gm) were deeply anesthetized with intraperitoneal sodium pentobarbital $(50 \mathrm{mg} / \mathrm{kg}$ of body weight) and decapitated in a guillotine. The brain was removed rapidly and placed in ice-cold $\left(0-1^{\circ} \mathrm{C}\right)$ artificial CSF (ACSF) bubbled 
with $100 \% \mathrm{O}_{2}$. The ACSF contained (in $\mathrm{mm}$ ): $140 \mathrm{NaCl}, 3 \mathrm{KCl}, 2.4$ $\mathrm{CaCl}_{2}, 1.3 \mathrm{MgSO}_{4}, 1.4 \mathrm{NaH}_{2} \mathrm{PO}_{4}, 11$ glucose, and 5 HEPES; $\mathrm{pH}$ was adjusted to 7.2-7.4 with $\mathrm{NaOH}$. Two coronal slices $(400 \mu \mathrm{m})$ containing the SON were sectioned. The slices were hemisectioned, and one hemisection was placed on the ramp of an interface recording chamber immediately after preparation. Heated ACSF $\left(32-34^{\circ} \mathrm{C}\right)$ was perfused through the chamber, and $100 \% \mathrm{O}_{2}$ was humidified and directed over the surface of the slice. The remaining hemisections were placed in a storage chamber containing ACSF at room temperature and gently bubbled with $100 \% \mathrm{O}_{2}$. The hemisection placed on the ramp was allowed to equilibrate in the recording chamber for $1.5-2 \mathrm{hr}$ before the start of experiments. After an experiment involving drugs that do not wash out from the preparation [e.g., tetrodotoxin (TTX) and steroids], the hemisection was removed, and a new section was placed into the chamber and allowed to equilibrate for $30 \mathrm{~min}$ before the start of experiments.

Electrodes and solutions. Patch electrodes (resistance, 3-6 M $\Omega$ ) were pulled from borosilicate glass $(1.65 \mathrm{~mm}$ outer diameter; $1.2 \mathrm{~mm}$ inner diameter; KG-33; Garner Glass) on a Flaming-Brown puller (Sutter Instruments). The pipette solution contained (in mM): $110 \mathrm{D}$-gluconic acid, $110 \mathrm{CsOH}, 10 \mathrm{CsCl}, 10 \mathrm{HEPES}, 1 \mathrm{NaCl}, 1 \mathrm{CaCl}_{2}, 1 \mathrm{MgCl}_{2}, 2$ Mg-ATP, 0.3 Na-GTP, and 11 EGTA; $\mathrm{pH}$ was adjusted to 7.2-7.4 with $\mathrm{CsOH}$. The osmolarity of the solution was $\sim 290 \mathrm{mOsm} . \mathrm{Cs}^{+}$was included in the solution in the place of $\mathrm{K}^{+}$to block potassium currents.

Recordings. Electrodes were placed in the SON under visual control and advanced through the slice in $2 \mu \mathrm{m}$ steps with a piezoelectric microdrive (Nanostepper; Scientific Precision Instruments) set at minimum speed and acceleration settings. A high-resistance seal $(>3 \mathrm{G} \Omega)$ was obtained, and the negative pressure was increased to cause the cell membrane to rupture, achieving the whole-cell configuration. Series resistance and whole-cell capacitance were adjusted and continually compensated during the experiment. Cells were identified as magnocellular neurons by the presence of a large transient, voltage-dependent potassium current, or A-current (Bourque, 1988). Cells were depolarized to $0 \mathrm{mV}$ (i.e., reversal for EPSCs), and their input resistance was calculated from the currents evoked by $-10,-20$, and $-30 \mathrm{mV}$ voltage steps. Cells were monitored in the first $15 \mathrm{~min}$ of the recordings for stability, and cells with unstable input resistance or series resistance were discarded. IPSCs were recorded with an Axopatch 1D amplifier (Axon Instruments) and stored on a VHS videocassette.

Data acquisition and analysis. All data were low-pass filtered with the amplifier at $2 \mathrm{kHz}$, digitized at $22 \mathrm{kHz}$ with a Neuro-Corder DR-484 digitizer unit, and stored on videotape for later analysis off-line. Selected data were digitized at $4-10 \mathrm{kHz}$ and recorded on a personal computer using the Digidata 1200 interface and pCLAMP software on-line (Axon Instruments). Segments of $180 \mathrm{sec}$ of synaptic activity were recorded during the experiment at a holding potential of $0 \mathrm{mV}$. The obtained traces were analyzed using DATAPAC III software (RUN Technology) to select synaptic events. Raw data were processed by taking the first derivative at each data point using a $7.5 \mathrm{msec}$ moving average. After this transformation, IPSCs were selected by the computer on the basis of a threshold set manually. The selected events were confirmed by eye, and detection errors were corrected manually. Event amplitudes and instantaneous event frequencies calculated by the program were exported and further analyzed in a spreadsheet (Excel; Microsoft Corporation). IPSCs were aligned by their peak amplitude and averaged, and average IPSC traces were analyzed using Clampfit (Axon Instruments). The decay phase of the average IPSC was fitted by a double exponential. Statistical analyses of the data were performed with the Wilcoxon signed rank test or Kruskal-Wallis ANOVA (depending on whether two or more experimental groups, respectively, were compared) for comparing the effects on the mean using SigmaStat (Jandel Scientific, Corte Madera, CA) and SPSS for Windows (SPSS Inc., Chicago, IL). Mean amplitude, frequency, and decay time constant values of IPSCs from individual cells were compared from control, wash-in, and washout periods using ANOVA for repeated measures. Changes in the decay time constant of IPSCs are expressed as the mean $\pm \mathrm{SE}$ of percent changes across cell groups. Probability values $<0.05$ were considered significant.

Pharmacology. The steroids allopregnanolone and $3 \beta$-hydroxy- $5 \alpha$ pregnan-20-one (isopregnanolone) were dissolved in $99.7 \%$ ethanol to produce a stock solution $(10 \mu \mathrm{g} / \mu \mathrm{l})$ after arrival in the laboratory and were stored at $-20^{\circ} \mathrm{C}$. On use, the steroid stock solution was dissolved in ACSF, giving an ethanol concentration $<0.03 \%$ for final drug concentrations of $1 \mu \mathrm{M}$. This concentration of ethanol does not affect spontaneous $\mathrm{GABA}_{\mathrm{A}}$ receptor-mediated IPSCs, as determined in a series of control experiments $(n=6)$. Steroids were bath applied at a final concentration of $1 \mu \mathrm{M}$. In experiments to test the effect of the intracellular application of allopregnanolone, the steroid from the stock solution was added to the patch solution (1 $\mu \mathrm{M}$ final steroid concentration), aliquotted, and stored at $-20^{\circ} \mathrm{C}$. The protein kinase blockers $\mathrm{H}-89$ (1 $\mu \mathrm{M}), \mathrm{Rp}$-8-bromo-guanosine 3',5'-cyclic monophosphorothioate (8-BrcGMPS; 5 and $40 \mu \mathrm{M}$ ), and bisindolylmaleimide (GF109203X; $500 \mathrm{nM}$ ) were dissolved in sterile water and stored at $-20^{\circ} \mathrm{C}$. On use, these chemicals were dissolved in ACSF and applied to the bath $15 \mathrm{~min}$ before the neurosteroid, and the application was continued during neurosteroid administration. For experiments in which G-protein function was blocked, GDP- $\beta$-S $(500 \mu \mathrm{M})$ was added, and GTP alone or GTP and ATP were omitted from the patch solution. For experiments in which G-protein or protein kinase C activity was stimulated, GTP- $\gamma$-S $(100 \mu \mathrm{M})$ or phorbol-12-myristate-13-acetate (PMA; $40 \mathrm{nM}$ ) was dissolved in the patch solution, aliquotted, and stored at $-20^{\circ} \mathrm{C}$ until use.

\section{RESULTS}

Within 1-2 min of establishing the whole-cell configuration, recorded neurons were identified as SON magnocellular neurons by the presence of a transient, voltage-dependent $\mathrm{K}^{+}$current, $I_{A}$ (Bourque, 1988). The recorded cells were then depolarized to 0 $\mathrm{mV}$ to isolate IPSCs. Spontaneous outward synaptic currents were identified as GABA-mediated IPSCs by blocking them with the bath application of the $\mathrm{GABA}_{\mathrm{A}}$ receptor antagonist bicuculline methiodide $(10 \mu \mathrm{M} ; n=5)$. A total of 85 cells were used in this study after an initial 15 min baseline recording period was established during which no run-down of IPSCs occurred and no change in the series resistance of the recording or in the input resistance of the cell was detected. Spontaneous IPSCs recorded in control conditions had an amplitude of $15-500 \mathrm{pA}$, a frequency of $0.2-7.0 \mathrm{~Hz}$, and a decay that was best fitted in individual IPSCs with a single-exponential function.

\section{Allopregnanolone effect on $\mathrm{GABA}_{\mathrm{A}}$ receptor-mediated IPSCs}

The effect of allopregnanolone $(1 \mu \mathrm{M})$ was investigated using a 15 min bath application of the steroid. IPSCs were collected over a 3 min period before and after 15 min of steroid application, and an ensemble average was calculated from each recording period, as shown in Figure 1. The decay phase of the averaged IPSCs was best fitted by a double-exponential function with a fast $\left(\tau_{1}\right)$ and a slow decay time constant $\left(\tau_{2}\right)$. The mean value for $\tau_{1}$ was $6.2 \pm 0.3$ msec, whereas the mean value for $\tau_{2}$ was $27.7 \pm 1.6 \mathrm{msec}(n=21)$. The relative contribution of $\tau_{2}$ to the peak amplitude of the IPSC was $38.2 \pm 5.2 \%$. Allopregnanolone increased $\tau_{1}$ to $7.1 \pm 0.2$ msec $(21.4 \pm 8.0 \%$ on average; $p<0.05$, paired Student's $t$ test; $n=21)$ and $\tau_{2}$ to $44.2 \pm 3.1 \mathrm{msec}(67.2 \pm 14.8 \%$ on average; $p<$ 0.001 , paired Student's $t$ test; $n=21$ ). This represented a $15.7 \pm$ $2.7 \%$ increase in the relative contribution of $\tau_{2}$ to the peak IPSC amplitude. Because the magnitude of the increase in $\tau_{2}$ was considerably larger than that in $\tau_{1}$, we focused our analysis on the slow decay time constant of the IPSC to study the effects of the neurosteroid.

After the start of the bath application of allopregnanolone, 7-11 min was required to detect the first IPSCs that showed a substantially longer decay, and the number of affected IPSCs increased with the time of the drug application. The effect continued to augment even after the termination of the steroid application, stabilizing 30-45 min after the initial exposure to the steroid. In experiments in which cells were recorded for longer durations, we found that the fast and the slow components of the average IPSC decay increased further 20-30 min after terminating the allopregnanolone application. The fast component increased to $8.3 \pm 0.7 \mathrm{msec}(36.2 \pm 10.5 \%$ mean percent change), and the slow component increased to $58.0 \pm 6.4 \mathrm{msec}(122.3 \pm$ 

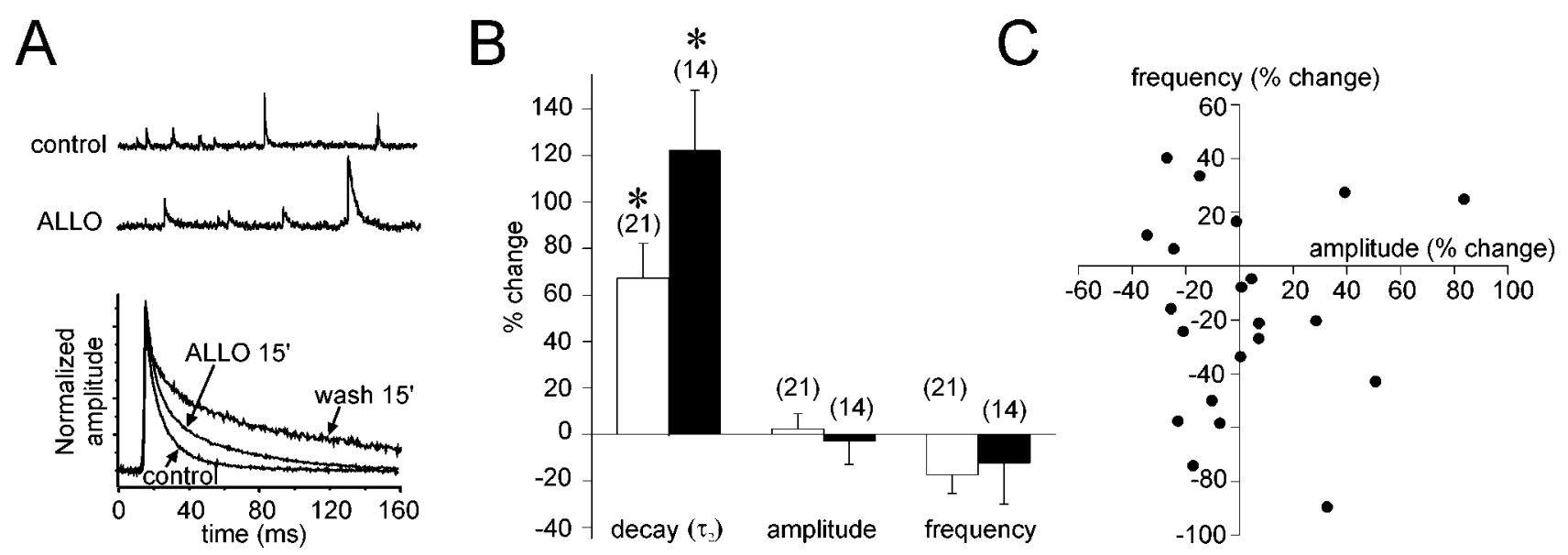

Figure 1. Allopregnanolone increases the decay time constant of IPSCs. $A$, Top, Spontaneous IPSCs recorded in control conditions (control) and after a 15 min bath application of allopregnanolone $(A L L O ; 1 \mu \mathrm{M})$ that caused a substantial increase in the IPSC decay. Bottom, Superimposed averages of IPSCs from the same cell recorded over 3 min periods in control conditions (control), after 15 min of allopregnanolone application ( $\left.A L L O 15^{\prime}\right)$, and after 15 min of washout of the allopregnanolone (wash $15^{\prime}$ ). The amplitudes of the mean IPSCs were normalized to control amplitudes. The slow IPSC decay time constant increased by $51.2 \%$, from 31.4 to $44.5 \mathrm{msec}$, after $15 \mathrm{~min}$ in allopregnanolone and increased further after the 15 min washout to stabilize at $272 \%$ of the control value $(117.2 \mathrm{msec})$. B. The changes in IPSC decay, amplitude, and frequency measured after a 15 min bath application of allopregnanolone $(1 \mu \mathrm{M}$; open bars) and a $15 \mathrm{~min}$ washout period (filled bars). The average of the slow decay time constant showed a significant increase in allopregnanolone $(+67.3 \pm 14.8 \%)$ and continued to increase during the 15 min washout period $(+122.3 \pm 25.8 \%)$. The average changes in IPSC amplitude $(+2.3 \pm 6.5 \%)$ and frequency $(-17.5 \pm 7.9 \%)$ were not significant. The numbers in parentheses indicate the number of cells tested. $C$, Scatter plot of changes in IPSC amplitude and frequency in individual cells. Although some cells showed a change in one or the other of the two parameters after a 15 min application of allopregnanolone $(1 \mu \mathrm{M})$, there was no correlation between the two in individual cells, nor were the changes consistent across the population.

$25.8 \%$ mean percent change; $n=14$ ) (Fig. $1 A, B)$. The effect of allopregnanolone was reversible but long lasting, requiring washout periods of $>60 \mathrm{~min}(n=4)$.

No significant changes in the amplitude $(64.8 \pm 7.0$ to $61.5 \pm$ $4.6 \mathrm{pA} ; 1.8 \pm 6.2 \%$ mean percent change) or the frequency $(1.9 \pm$ 0.3 to $1.3 \pm 0.2 \mathrm{~Hz} ;-17.5 \pm 7.9 \%$ mean percent change) of averaged IPSCs were seen with allopregnanolone application when the recorded cells were analyzed as a group (Fig. 1B). However, some cells did show changes in IPSC frequency and amplitude that were significant in within-cell comparisons, although these changes were not consistent throughout the population of recorded cells (Fig. 1C). The experiments were repeated in TTX $(1.5 \mu \mathrm{M})$ to determine whether the trend toward a decrease in IPSC frequency was caused by a presynaptic, spikemediated action of allopregnanolone. Whereas the allopregnanolone effect on the IPSC decay was retained in TTX, the effect on the IPSC frequency was completely blocked (2.2 \pm 0.6 vs $1.9 \pm 0.3 \mathrm{~Hz}$ in control; $-0.2 \pm 7.3 \%$ mean percent change; $n=8$ ), suggesting a presynaptic inhibitory action of the allopregnanolone that reduced the IPSC frequency in some cells.

The specificity of the steroid effect was determined in control experiments using isopregnanolone, a physiologically inactive stereoisomer of allopregnanolone. The effect of isopregnanolone was tested at $1 \mu \mathrm{M}(n=5)$ and $10 \mu \mathrm{M}(n=4)$ concentrations to ensure that steroid application did not cause changes in the membrane structure that led to a nonspecific modulation of the synaptic currents. Isopregnanolone did not change significantly the IPSC decay phase (at $1 \mu \mathrm{M}, \tau_{2}, 33.0 \pm 2.5 \mathrm{vs} 31.4 \pm 2.8 \mathrm{msec}$ in controls; mean percent change $=+6.6 \pm 6.7 \%$; at $10 \mu \mathrm{M}, \tau_{2}$, $35.9 \pm 5.2 \mathrm{vs} 33.2 \pm 2.6 \mathrm{msec}$ in controls; mean percent change $=$ $12.9 \pm 14.9 \%$ ) (Fig. $2 A, C$ ), amplitude (at $1 \mu \mathrm{M}, 78.6 \pm 15.9$ vs $77.5 \pm 17.2 \mathrm{pA}$; mean percent change $=-4.3 \pm 5.9 \%$; at $10 \mu \mathrm{M}$, $53.4 \pm 5.0$ vs $71.7 \pm 15.0 \mathrm{pA}$ in controls; mean percent change $=$ $-21.0 \pm 7.4 \%$ ), or frequency (at $1 \mu \mathrm{M}, 1.0 \pm 0.2$ vs $1.2 \pm 0.3 \mathrm{~Hz}$ in controls; mean percent change $=2.3 \pm 12.0 \%$; at $10 \mu \mathrm{M}, 1.6 \pm$ 0.3 vs $2.4 \pm 1.4 \mathrm{~Hz}$ in controls; mean percent change $=6.1 \pm$ $23.9 \%$ ).

To ensure that the increase in the IPSC decay time constant caused by allopregnanolone was not attributable to a change in the passive electrical properties of the recorded cells, we also investigated allopregnanolone's effect on the frequency, amplitude, and decay of the EPSCs recorded at a holding potential of $-70 \mathrm{mV}$. We found no changes in any of the properties of the EPSCs (data not shown).

To confirm that allopregnanolone's actions were mediated by binding to an extracellular site, we applied allopregnanolone (1 $\mu \mathrm{M})$ directly into the cell cytosolic compartment by including it in the patch solution. It is estimated that the electrode solution equilibrates completely with the cell's internal solution within $\sim 3$ min of achieving the whole-cell configuration (Marty and Neher, 1983). IPSCs were recorded immediately after rupturing the cell membrane to obtain control values and then again after $15 \mathrm{~min}$ of recording. Allopregnanolone applied intracellularly had no significant effect on the decay phase $\left(\tau_{2}, 29.9 \pm 3.9 \mathrm{vs} 28.0 \pm 2.8 \mathrm{msec}\right.$ in controls; mean percent change $=5.8 \pm 8.1 \%$; $n=8$ ), amplitude $(56.8 \pm 8.1$ vs $55.7 \pm 7.1 \mathrm{pA}$ in controls; mean percent change $=-2.8 \pm 6.8 \%)$, or frequency $(0.7 \pm 0.1$ vs $0.8 \pm 0.2 \mathrm{~Hz}$ in controls; mean percent change $=4.3 \pm 13.1 \%)$ of the IPSCs (Fig. 2B,C), indicating that the steroid does not bind to an intracellular receptor to modulate the GABA currents.

\section{G-protein dependence of the allopregnanolone effect}

We tested whether G-proteins play a role in the modulation by allopregnanolone of GABA IPSCs by blocking G-protein activity. A G-protein antagonist, the nonhydrolyzable GDP analog GDP- $\beta$-S $(500 \mu \mathrm{M})$, was included in the patch solution, and GTP $(n=6)$ or both GTP and ATP $(n=4)$ were omitted from the patch solution. The GDP- $\beta$-S solution was allowed to diffuse into 

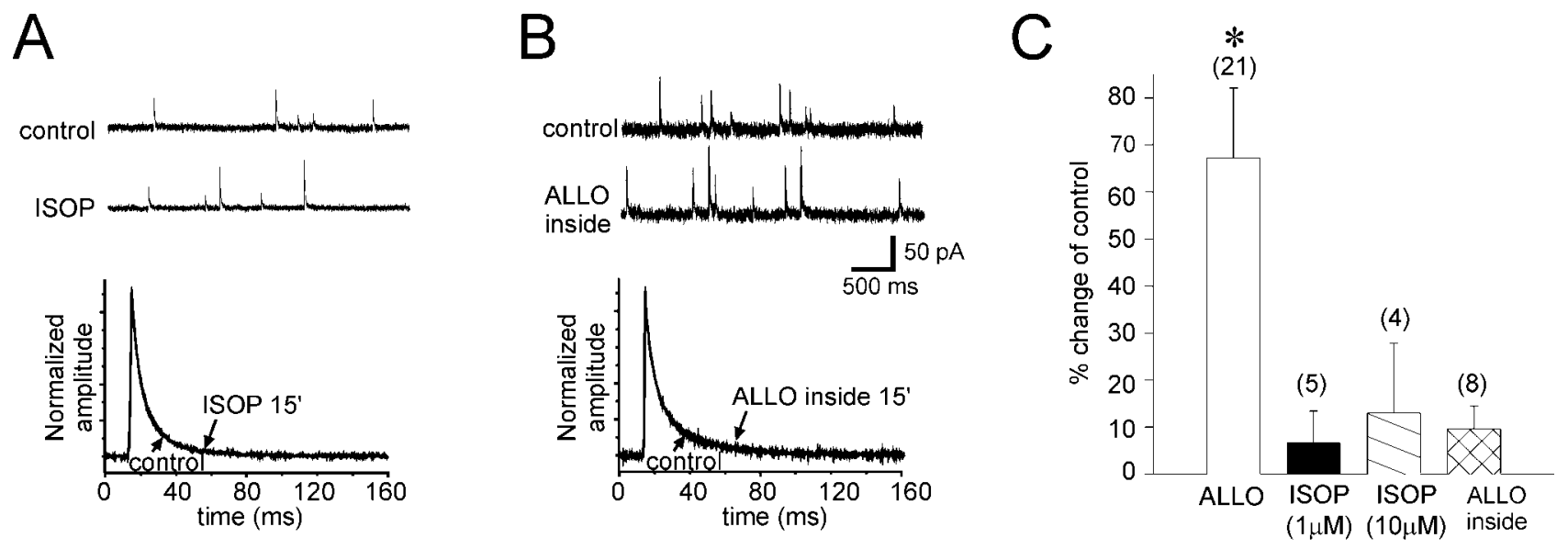

Figure 2. Bath application of isopregnanolone and intracellular application of allopregnanolone had no effect on IPSCs. $A$, Top, Spontaneous IPSCs were recorded in control conditions (control) and after a $15 \mathrm{~min}$ bath application of the physiologically inactive stereoisomer of allopregnanolone, isopregnanolone (ISOP; $1 \mu \mathrm{M}$ ). Bottom, Superimposed averages of IPSCs from the same cells recorded over 3 min periods in control ACSF (control) and after $15 \mathrm{~min}$ of isopregnanolone application (ISOP 15') are shown. B, Top, Spontaneous IPSCs before (control) and after 15 min of intracellular application of allopregnanolone ( $A L L O$ inside $; 1 \mu \mathrm{M})$ are shown. Bottom, Superimposed averages of IPSCs from the same cells before (control) and after a $15 \mathrm{~min}$ intracellular application of allopregnanolone $\left(A L L O\right.$ inside $\left.15^{\prime}\right)$ are shown. $C$, The slow decay time constant increased $67.3 \pm 14.8 \%$ after a 15 min allopregnanolone application $(A L L O)$ compared with control values $\left({ }^{*} p<0.001\right.$, paired $t$ test; $\left.n=21\right)$. The changes in IPSC decay were nonsignificant after a $15 \mathrm{~min}$ application of isopregnanolone at $1 \mu \mathrm{M}[I S O P(1 \mu \mathrm{M}), 6.6 \pm 6.7 \% ; n=5]$ and at $10 \mu \mathrm{M}[I S O P(10 \mu \mathrm{M}), 12.9 \pm 14.9 \% ; n=$ 4] and after $15 \mathrm{~min}$ of intracellular allopregnanolone application ( $A L L O$ inside, $9.6 \pm 4.8 \% ; n=8)$.
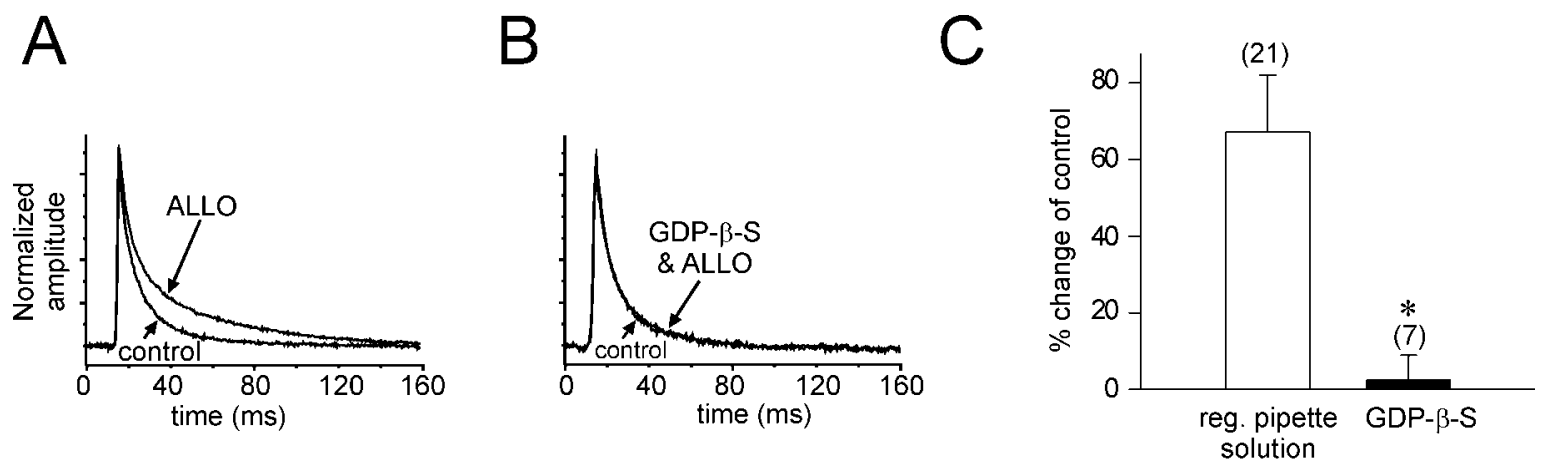

Figure 3. G-Protein dependence of the allopregnanolone effect. The G-protein dependence of the allopregnanolone effect on the IPSC slow decay was tested by inhibiting G-protein activity with GDP- $\beta$-S $(500 \mu \mathrm{M})$ and $0 \mathrm{~mm}$ ATP and/or GTP applied intracellularly. Averages of IPSCs over 3 min were normalized and superimposed. $A$, The slow component of the average IPSC decay increased after a 15 min application of allopregnanolone ( $A L L O)$ by an average of $51.2 \%$ in a control cell. $B$, Allopregnanolone had no effect after intracellular application of the GDP- $\beta$-S solution $(G D P-\beta-S \& A L L O)$. $C$, The average change in the slow IPSC decay was $67.3 \pm 14.8 \%$ in control cells and $2.4 \pm 6.5 \%$ in cells perfused with GDP- $\beta$-S $(n=7 ; * p<0.01$, Wilcoxon rank sum test). reg., Regular.

the cells for $15 \mathrm{~min}$ before the start of the allopregnanolone $(1$ $\mu \mathrm{M})$ application in the bath. Whereas the GDP- $\beta$-S solution had no effect on the frequency or amplitude of IPSCs, it completely blocked the effect of allopregnanolone on the IPSC decay phase (GTP omitted, $51.2 \pm 10.2$ vs $47.3 \pm 7.94$ msec in controls; mean percent change $=6.2 \pm 14.1 \% ; n=6$; NS; GTP and ATP omitted, $45.9 \pm 6.5 \mathrm{vs} 44.4 \pm 5.5 \mathrm{msec}$ in controls; mean percent change $=4.3 \pm 8.5 \% ; n=4$; NS) (Fig. 3).

\section{Protein kinase dependence of the allopregnanolone effect}

The G-protein dependence of the modulation of GABA IPSCs by allopregnanolone suggests that the steroid's actions may be mediated by protein phosphorylation. To determine whether phosphorylation is required for the expression of the allopregnanolone effect, protein kinase inhibitors selective for PKC, PKA, and the cGMP-dependent protein kinase (PKG) were tested.
Treatment of the slices with the specific PKC antagonist bisindolylmaleimide (500 nM) completely abolished the effect of allopregnanolone on the IPSC slow decay $(41.9 \pm 4.0$ vs $36.7 \pm 2.4$ msec in controls; mean percent change $=2.5 \pm 3.2 \% ; n=5$ ) (Fig. $4 B$ ). Treatment of the slices with the PKA antagonist H-89 (1 $\mu \mathrm{M})$ resulted in a nonsignificant change in the IPSC decay in response to allopregnanolone $(55.6 \pm 13.3 \mathrm{vs} 37.4 \pm 4.3 \mathrm{msec}$ in controls; mean percent change $=28.0 \pm 18.9 \% ; n=5$; NS) (Fig. $4 C)$. Treatment with the PKG inhibitor Rp-8-Br-cGMPS (5 and $40 \mu \mathrm{M})$ did not attenuate the allopregnanolone effect on the slow decay time constant of IPSCs (at $5 \mu \mathrm{M}, 74.5 \pm 18.0 \mathrm{vs} 42.8 \pm 2.3$ msec in controls; mean percent change $=73.9 \pm 32.9 \%$; $n=5$; at $40 \mu \mathrm{M}, 68.1 \pm 6.8$ vs $32.3 \pm 3.1 \mathrm{msec}$ in controls; mean percent change $=80.1 \pm 20.1 \% ; n=5)($ Fig. $4 D)$. Blockade of allopregnanolone's actions by the PKC inhibitor was significant $(p<$ 0.05), whereas the effect of the PKA and PKG blockers was nonsignificant (Kruskal-Wallis ANOVA on ranks) (Fig. 4E). 

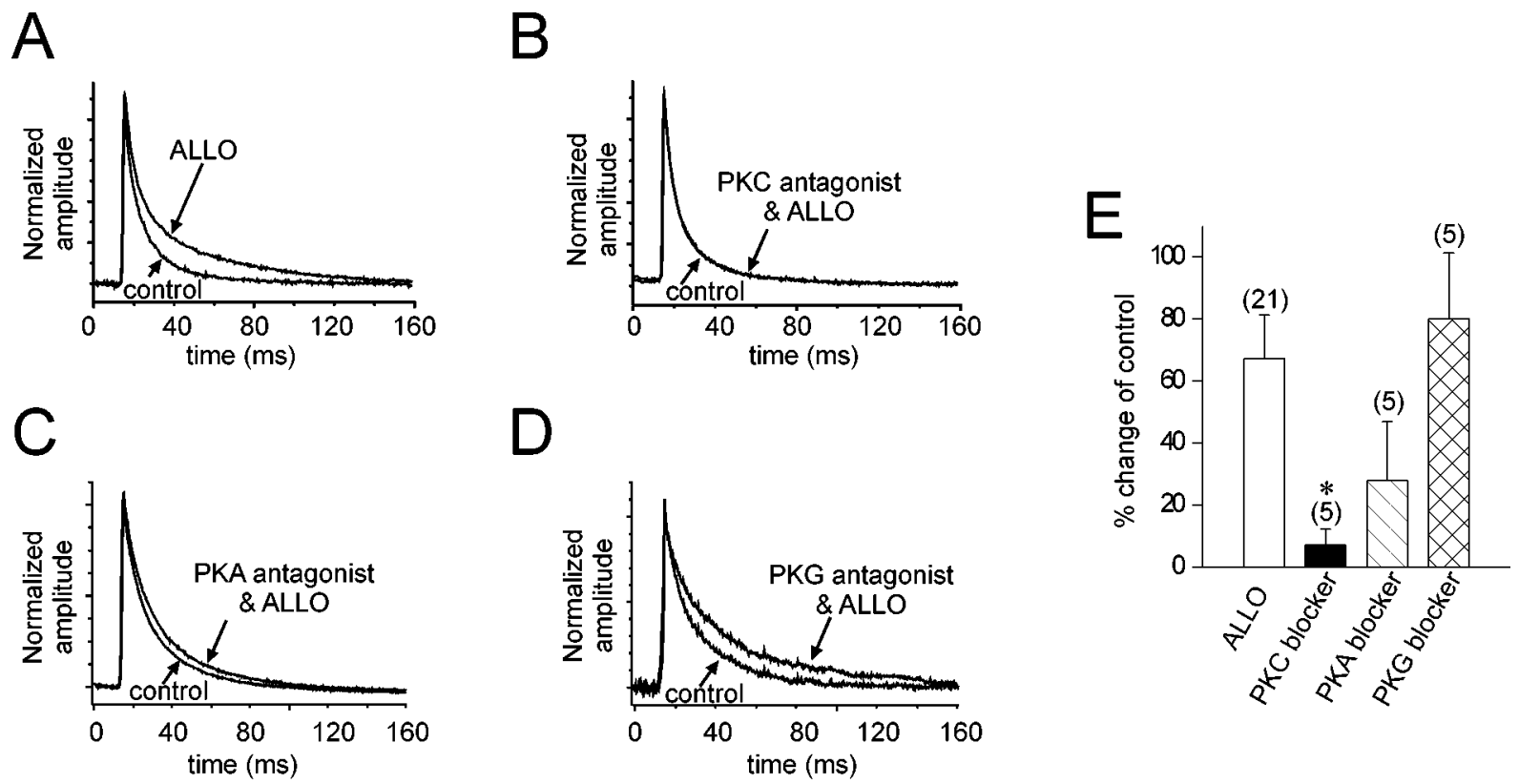

Figure 4. Protein kinase dependence of the allopregnanolone modulation of IPSCs. Averages of IPSCs recorded over 3 min in control and in allopregnanolone $(1 \mu \mathrm{M} ; 15 \mathrm{~min})$ with and without the addition of protein kinase antagonists. $A$, The mean IPSCs in control (control) and in allopregnanolone $(A L L O)$ were normalized and superimposed. $B-D$, The application of allopregnanolone was preceded by the bath application of membrane permeable blockers of PKC (bisindolylmaleimide, $500 \mathrm{nM} ; B ; P K C$ antagonist \& $A L L O)$, PKA (H-89, $1 \mu \mathrm{M} ; C ; P K A$ antagonist \& $A L L O)$, and PKG (Rp-8-Br-cGMPS, $40 \mu \mathrm{M} ; D ; P K G$ antagonist \& $A L L O)$. The PKC antagonist completely abolished the effect of allopregnanolone (B), the PKA antagonist partially blocked the effect $(C)$, and the PKG antagonist appeared to have no effect on the allopregnanolone-induced increase in IPSC decay $(D) . E$, The average change in the slow decay of IPSCs caused by allopregnanolone in the absence and presence of protein kinase antagonists is shown. The effect of allopregnanolone $(A L L O$; control \% change, $+67.3 \pm 14.8 \%)$ was significantly inhibited by the PKC blocker $(\%$ change, $+6.8 \pm 5.3 \% ; n=$ $\left.5 ;{ }^{*} p<0.05\right)$ but not by the PKA blocker $(\%$ change, $+28.0 \pm 18.9 \% ; n=5)$ and was not changed by the PKG blocker $(\%$ change, $+80.1 \pm 20.1 \% ; n=$ 5) (Kruskal-Wallis one-way ANOVA on ranks; post hoc Dunn's test).
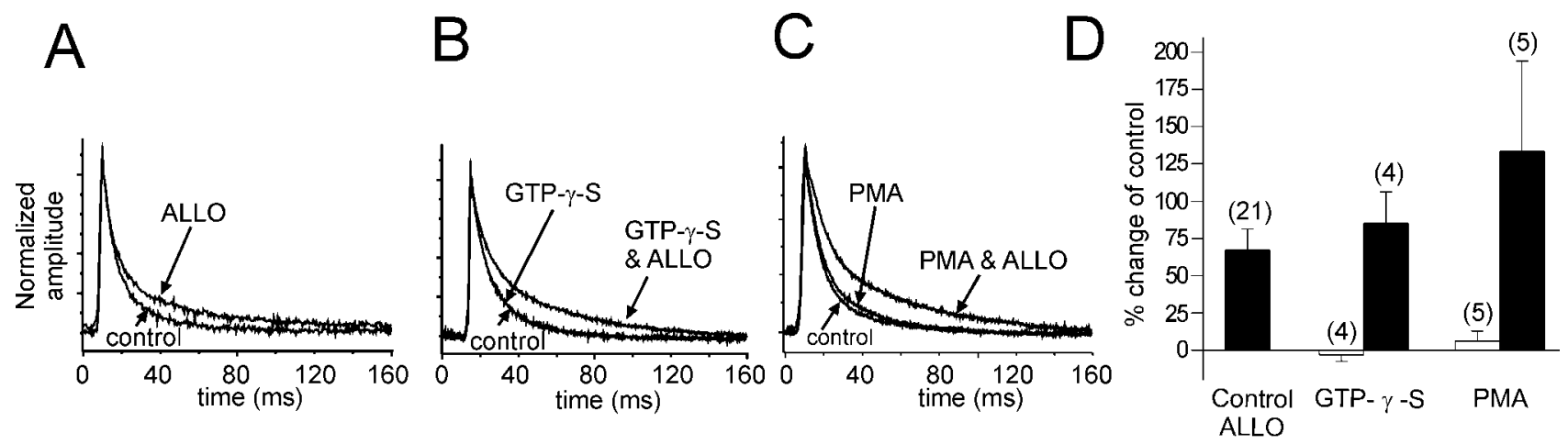

Figure 5. Activation of G-proteins or PKC has no effect on IPSCs in the absence of allopregnanolone. $A$, A 15 min application of allopregnanolone caused a $53.7 \%$ change in the slow IPSC $(A L L O)$ in a control cell. $B$, The slow IPSC decay was unaffected by the intracellular application of GTP- $\gamma$-S for $15 \mathrm{~min}(G T P-\gamma-S)$ compared with the IPSC decay at break-in (control). Note that control and $G T P-\gamma-S$ traces overlap completely. A subsequent 15 min application of allopregnanolone increased the slow IPSC decay by $90.2 \%(G T P-\gamma-S \& A L L O)$. $C$, Intracellular application of the PKC agonist PMA $(40 \mathrm{nM})$ had very little effect on the slow IPSC decay $(+8.1 \% ; P M A)$ compared with the averaged IPSCs recorded at break-in (control). Subsequent allopregnanolone application $(1 \mu \mathrm{M})$ caused a $219.4 \%$ change in the IPSC decay (PMA\&ALLO). D, The average percent changes in the slow IPSC decay with stimulation of G-protein and PKC activity are shown. Allopregnanolone caused a $67.3 \pm 14.8 \%$ average increase in the slow IPSC decay (Control $A L L O)$. The IPSC decay changed an average of $-2.9 \pm 1.3 \%$ with GTP- $\gamma-\mathrm{S}$ perfusion alone (open bar; GTP- $\gamma-S)$ and $+85.2 \pm 21.3 \%$ in allopregnanolone $(15 \mathrm{~min})$ after intracellular perfusion of GTP- $\gamma-\mathrm{S}(15 \mathrm{~min}$; filled bar $)$. The IPSC decay increased by an average of $6.3 \pm 6.7 \%$ with PMA perfusion alone (open bar; PMA) and by $129.5 \pm 62.0 \%$ with allopregnanolone application (15 min) after intracellular perfusion of PMA (15 min; filled bar).

\section{Steroid activation of a G-protein- and protein kinase-coupled receptor}

The G-protein and protein kinase dependence of the allopregnanolone effect on IPSCs suggested that the steroid may be acting at a separate, G-protein-coupled receptor. We tested this hypothesis by stimulating G-protein and PKC activity in an attempt to mimic the effect of allopregnanolone. Inclusion of the G-protein agonist GTP- $\gamma$-S $(100 \mu \mathrm{M})$ in the pipette solution did not alter the decay of GABA IPSCs (Fig. 5B). However when the intracellular application of GTP- $\gamma$-S was followed by the bath application of allopregnanolone $(1 \mu \mathrm{M})$, the steroid's effect on the decay time constant of IPSCs was not significantly different from the effect of allopregnanolone without intracellular GTP- $\gamma-\mathrm{S}\left(\tau_{2}\right.$ with GTP$\gamma-\mathrm{S}, 61.2 \pm 4.2$ vs $34.5 \pm 5.1 \mathrm{msec}$ in controls; mean percent 
change $=+85.2 \pm 21.3 \% ; n=4 ; \tau_{2}$ without GTP- $\gamma-\mathrm{S}, 44.2 \pm 3.1$ vs $27.7 \pm 1.6 \mathrm{msec}$ in controls; mean percent change $=+67.3 \pm$ $14.8 \%)$.

The PKC activator PMA (40 nM) was applied intracellularly through the recording pipette in five cells (Fig. 5C). PMA had no effect on the decay time constant of the IPSCs $(37.9 \pm 1.2 \mathrm{vs}$ $36.0 \pm 3.3 \mathrm{msec}$ in controls; mean percent change $=+6.3 \pm 6.7 \%$; $n=5)$. The effect of allopregnanolone on the IPSC decay after PMA application was not significantly different $(80.4 \pm 18.4$ vs $36.0 \pm 3.3 \mathrm{msec}$ in controls; mean percent change $=+129.6 \pm$ $62.0 \%$ ) in these cells compared with the allopregnanolone effect in the absence of PMA (44.2 \pm 3.1 vs $27.7 \pm 1.6 \mathrm{msec}$ in controls; mean percent change $=+67.3 \pm 14.8 \%$ ) (Fig. $5 C$ ). Thus, in magnocellular neurons of the supraoptic nucleus, the actions of allopregnanolone seem not to be mediated by the activation of a separate G-protein- and protein kinase-coupled receptor, because the steroid effect is not mimicked by exogenous activation of G-proteins or PKC.

\section{DISCUSSION}

In our experiments on hypothalamic magnocellular neurons, the neurosteroid allopregnanolone caused an increase in the time constant of decay of spontaneous, GABA-mediated IPSCs. No consistent effect of the neurosteroid on either the amplitude or the frequency of the IPSCs was observed. A trend toward a neurosteroid-induced decrease in the frequency of spontaneous IPSCs was abolished by TTX, suggesting that allopregnanolone may also enhance inhibition in local presynaptic GABA neurons. These findings corroborate those of Brussaard et al. (1997), who also found a neurosteroid effect on the decay phase, but not on the amplitude or frequency, of spontaneous IPSCs recorded in the same cells. Zhang and Jackson (1994) found similar effects of allopregnanolone and of a related steroid, alphaxalone, on GABA currents recorded in the magnocellular nerve terminals in the neurohypophysis. Thus, the main effect of the neurosteroid on magnocellular neurons appears to be to change the decay kinetics of synaptic GABA currents, without altering the probability of GABA release or the postsynaptic sensitivity to GABA. Different actions of neuroactive steroids on synaptic GABA signals have been reported in various other cell preparations, including the neurointermediate lobe of the pituitary. Using hypothalamicpituitary cocultures, Poisbeau et al. (1997) reported an allopregnanolone-induced increase in the frequency and amplitude, but no effect on the decay, of spontaneous IPSCs recorded in neurointermediate pituitary cells. IPSCs recorded in spinal neurons of Xenopus laevis underwent an increase in the frequency as well as the decay in response to a related steroid, $5 \beta$-pregnan$3 \alpha$-ol-20-one (Reith and Sillar, 1997). These results suggest that the effects of neurosteroids on GABAergic synaptic transmission are highly dependent on the subunit composition of the $\mathrm{GABA}_{\mathrm{A}}$ receptors and on the specific neural environment, which show considerable diversity in different brain regions (Zhang et al., 1991; Criswell et al., 1993; Benke et al., 1994; Inglefield et al., 1994; Fenelon et al., 1995; Dunn et al., 1996; Huntsman et al., 1996; Mize and Butler, 1997).

The effect of allopregnanolone in our preparation, as in others (Peters et al., 1988; Le Foll et al., 1997; Calogero et al., 1998), was stereospecific and not a consequence of a nonspecific steroid action on the cell membrane, because the physiologically inactive allopregnanolone isomer isopregnanolone did not show any effect on the GABA currents. Although the precise location of the allopregnanolone binding site on the $\mathrm{GABA}_{\mathrm{A}}$ receptor is not known, it is presumed that the steroid binds to a portion of the receptor that is buried in the lipophilic phospholipid bilayer (Baulieu, 1998; Rick et al., 1998). On the basis of our results and those of others (Lambert et al., 1990), this binding site appears to be accessible only from the outside of the cell, because intracellular application of the steroid had no effect.

The initial effect of the steroid occurred slowly, after 7-11 min, and increased in magnitude with time during the allopregnanolone application and for 15-30 min into washout of the steroid. This suggests that considerable time was required to reach a physiologically effective concentration of the steroid in the slice preparation. The slow onset together with the slow reversal (>60 min) of the allopregnanolone effect was probably caused by the steroid's lipophilic nature, which would account for the slow equilibration of the steroid concentration in the slice with wash-in and its slow clearing with washout.

Blockade of G-protein function and PKC activity abolished the allopregnanolone-mediated slowing of the IPSC decay, suggesting that the steroid may act via a separate G-protein-coupled receptor. However, exogenous activation of G-proteins or PKC in the absence of allopregnanolone failed to mimic the effect of the neurosteroid on IPSCs, indicating that the steroid did not activate a separate G-protein- and protein kinase-signaling pathway. Thus, it seems that direct binding of the neurosteroid to the $\mathrm{GABA}_{\mathrm{A}}$ receptor is required for modulation of the GABA IPSCs, but its binding and/or effectiveness is G-protein and protein kinase dependent. This suggests a mechanism by which neurosteroid binding and kinase-mediated phosphorylation must be coincident to alter GABA currents. In Figure 6, we provide two possible models that account for these observations. In the first case, the $\mathrm{GABA}_{\mathrm{A}}$ receptor must be in a phosphorylated state for the steroid to bind to the receptor, and blocking phosphorylation (i.e., favoring dephosphorylation) prevents the steroid from binding (Fig. 6A). In the second case, binding of the steroid causes a conformational change in the $\mathrm{GABA}_{\mathrm{A}}$ receptor that exposes phosphorylation sites in the protein that were previously inaccessible to protein kinase (Fig. $6 B$ ). Phosphorylation of the $\mathrm{GABA}_{\mathrm{A}}$ receptor is then catalyzed by constitutive kinase activity. The proposed models account for the allosteric modulation of the $\mathrm{GABA}_{\mathrm{A}}$ receptor by the neurosteroid (Majewska, 1990; Hawkinson et al., 1994; Lambert et al., 1995; Maitra and Reynolds, 1998), as well as the requirement for phosphorylation of the receptor by continuous kinase activity. Other molecular mechanisms could also explain these findings, including phosphorylation of other proteins associated with the $\mathrm{GABA}_{\mathrm{A}}$ receptor, such as gephyrin (Giustetto et al., 1998), rapsyn (Yang et al., 1997), and GABA receptor-associated protein (Wang et al., 1999), as well as the inhibition of phosphatase activity.

Neurosteroid efficacy in modulating $\mathrm{GABA}_{\mathrm{A}}$ receptormediated currents is mainly influenced by the $\alpha$ and $\gamma$ subunit subtypes of the $\mathrm{GABA}_{\mathrm{A}}$ receptor (Shingai et al., 1991; Zaman et al., 1992; Maitra and Reynolds, 1998, 1999). The GABA receptors in magnocellular neurons are comprised of $\alpha 1, \alpha 2, \beta 2 / 3$, and $\gamma 2$ subunits (Fenelon and Herbison, 1995, 1996; Fenelon et al., 1995). The expression of $\alpha 1$ and $\alpha 2$ subunits changes in magnocellular neurons during parturition and lactation, resulting in the $\alpha 1$-to- $\alpha 2$ ratio increasing from $1 / 1$ to $1 / 4$ (Brussaard et al., 1997, 1999). This change in $\alpha$ subunit expression parallels a change in the decay time constant of spontaneous IPSCs and in the neurosteroid sensitivity of the $\mathrm{GABA}_{\mathrm{A}}$ receptor (Brussaard et al., 1999). Changes in $\gamma 2$ subunit expression have also been reported in magnocellular neurons during lactation, although these 

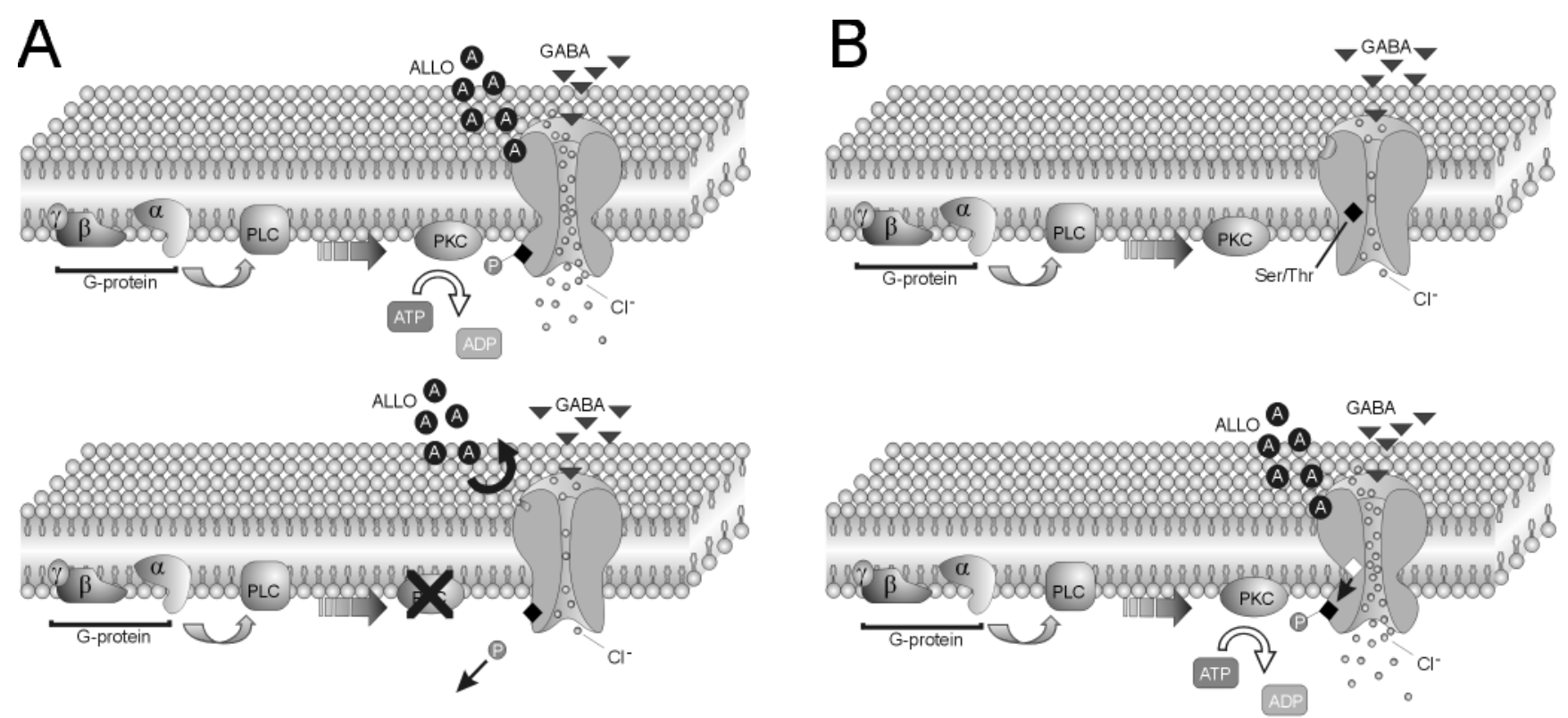

Figure 6. Models of G-protein and protein kinase dependence of $\mathrm{GABA}_{\mathrm{A}}$ receptor modulation by allopregnanolone. Our findings suggest that phosphorylation of $\mathrm{GABA}_{\mathrm{A}}$ receptors is necessary for the neurosteroid regulation of synaptic GABA currents, although enhancing G-protein and PKC activity alone is not sufficient to mimic the effect of the neurosteroid. This codependence on receptor phosphorylation and steroid presence can be explained by the following two models. $A$, Top, The first model is one in which the $\mathrm{GABA}_{\mathrm{A}}$ receptor is constitutively phosphorylated $(P)$, allowing the neurosteroid $(A L L O ; A)$ to bind and increase channel opening and chloride flux. Bottom, Blocking G-protein and/or PKC activity leads to dephosphorylation of the channel, causing a conformational change in the receptor protein that prevents the neurosteroid from binding. $B$, Top, In the

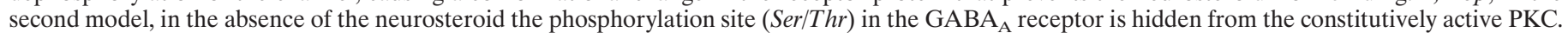
Bottom, After allopregnanolone binding, a conformational change in the $\mathrm{GABA}_{\mathrm{A}}$ receptor occurs, and the Ser/Thr residue(s) (open diamond) becomes exposed for phosphorylation by $\mathrm{PKC}$, increasing channel opening and chloride influx. PLC, Phospholipase C.

changes appear to be specific to vasopressin-secreting neurons of the paraventricular nucleus (Fenelon and Herbison, 1996). Thus, changes in the neurosteroid sensitivity of the $\mathrm{GABA}_{\mathrm{A}}$ receptor may be a result of differential receptor subtype expression under different physiological conditions, which may influence the phosphorylation state of the receptor.

The $\alpha 1$ and $\alpha 2$ subunits of the receptor, although playing a major role in determining the $\mathrm{GABA}_{\mathrm{A}}$ receptor's sensitivity to allopregnanolone, have not been shown to be phosphorylated by PKC (Kellenberger et al., 1992; Moss et al., 1992). However, the $\gamma 2$ subunit is phosphorylated by PKC on the Ser327 and Ser343 residues (Krishek et al., 1994). Thus, the importance of the $\gamma 2$ subunit for the neurosteroid modulation of GABA currents together with our finding of a phosphorylation dependence of the neurosteroid effect on IPSCs suggests that the neurosteroidmediated phosphorylation of the $\mathrm{GABA}_{\mathrm{A}}$ receptor may be occurring at the $\gamma 2$ subunit. (Kellenberger et al., 1992; Moss et al., 1992; Lin et al., 1996).

Outside-out patch recordings have revealed that allopregnanolone modulates both the open time and opening frequency of the $\mathrm{GABA}_{\mathrm{A}}$ receptor channel (Lambert et al., 1990; Puia et al., 1990; Twyman and Macdonald, 1992). The fact that allopregnanolone modulation is sustainable in the outside-out patch configuration, in which GABA receptors are isolated in an excised patch of membrane, suggests either that receptor phosphorylation is maintained after excision or that the G-protein and protein kinase machinery is closely associated with the $\mathrm{GABA}_{\mathrm{A}}$ receptor. The close association of an unknown protein kinase with the $\mathrm{GABA}_{\mathrm{A}}$ receptor complex has been demonstrated using purified receptor preparations (Sweetnam et al., 1988; Bureau and Laschet, 1995).
The slow decay phase of biexponentially decaying GABA currents has been attributed to the desensitization and reopening of the $\mathrm{GABA}_{\mathrm{A}}$ receptor channels (Jones and Westbrook, 1995). The neurosteroid $3 \alpha$,21dihydroxy-5 $\alpha$-pregnan-20-one (THDOC) has been shown to prolong the slow deactivation of GABA-mediated currents by slowing the recovery of $\mathrm{GABA}_{\mathrm{A}}$ receptors from the desensitized state (Zhu and Vicini, 1997). We found that allopregnanolone slowed both the fast decay phase and the slow decay phase of synaptic IPSCs, although the effect on the slow deactivation of the IPSCs was considerably more pronounced. This suggests that, like THDOC, allopregnanolone may also be affecting the time course of recovery of $\mathrm{GABA}_{\mathrm{A}}$ receptors from desensitization. Enhancing or maintaining phosphorylation of the $\mathrm{GABA}_{\mathrm{A}}$ receptors in hippocampal neurons by blocking phosphatase activity has been shown to increase the decay kinetics of IPSCs (Jones and Westbrook, 1997). Our findings indicate that phosphorylation of $\mathrm{GABA}_{\mathrm{A}}$ receptors in hypothalamic neurons is necessary for allopregnanolone to cause a decrease in the decay kinetics of synaptic IPSCs. This suggests either that the ongoing phosphorylation necessary for the neurosteroid's effect targets sites on the $\mathrm{GABA}_{\mathrm{A}}$ receptor different from those of the phosphorylation caused by blocking phosphatase activity or that there are differences in the effects of phosphorylation on $\mathrm{GABA}_{\mathrm{A}}$ receptors in hippocampal and hypothalamic neurons.

Our finding that $\mathrm{GABA}_{\mathrm{A}}$ receptor modulation by allopregnanolone is G-protein and protein kinase dependent, although it may be unique to $\mathrm{GABA}_{\mathrm{A}}$ receptors expressing the subunit composition found in hypothalamic magnocellular neurons, indicates a new level of complexity in the regulation of $\mathrm{GABA}_{\mathrm{A}}$ receptor physiology by neurosteroids. 


\section{REFERENCES}

Baulieu EE (1998) Neurosteroids: a novel function of the brain. Psychoneuroendocrinology 23:963-987.

Benke D, Fritschy JM, Trzeciak A, Bannwarth W, Mohler H (1994) Distribution, prevalence, and drug binding profile of gammaaminobutyric acid type A receptor subtypes differing in the betasubunit variant. J Biol Chem 269:27100-27107.

Bixo M, Andersson A, Winblad B, Purdy RH, Backstrom T (1997) Progesterone, 5alpha-pregnane-3,20-dione and 3alpha-hydroxy-5alphapregnane-20-one in specific regions of the human female brain in different endocrine states. Brain Res 764:173-178.

Bourque CW (1988) Transient calcium-dependent potassium current in magnocellular neurosecretory cells of the rat supraoptic nucleus. J Physiol (Lond) 397:331-347.

Brussaard AB, Kits KS, Baker RE, Willems WP, Leyting-Vermeulen JW, Voorn P, Smit AB, Bicknell RJ, Herbison AE (1997) Plasticity in fast synaptic inhibition of adult oxytocin neurons caused by switch in GABA(A) receptor subunit expression. Neuron 19:1103-1114.

Brussaard AB, Devay P, Leyting-Vermeulen JL, Kits KS (1999) Changes in properties and neurosteroid regulation of GABAergic synapses in the supraoptic nucleus during the mammalian female reproductive cycle. J Physiol (Lond) 516:513-524.

Bureau MH, Laschet JJ (1995) Endogenous phosphorylation of distinct gamma-aminobutyric acid type A receptor polypeptides by Ser/Thr and Tyr kinase activities associated with the purified receptor. J Biol Chem 270:26482-26487.

Calogero AE, Palumbo MA, Bosboom AM, Burrello N, Ferrara E, Palumbo G, Petraglia F, D'Agata R (1998) The neuroactive steroid allopregnanolone suppresses hypothalamic gonadotropin-releasing hormone release through a mechanism mediated by the gammaaminobutyric acid A receptor. J Endocrinol 158:121-125.

Cheney DL, Uzunov D, Costa E, Guidotti A (1995) Gas chromatographic-mass fragmentographic quantitation of $3 \forall$-hydroxy$5 \forall$-pregnan-20-one (allopregnanolone) and its precursors in blood and brain of adrenalectomized and castrated rats. J Neurosci 15:4641-4650.

Corpechot C, Young J, Calvel M, Wehrey C, Veltz JN, Touyer G, Mouren M, Prasad VV, Banner C, Sjovall J (1993) Neurosteroids: 3 alpha-hydroxy-5 alpha-pregnan-20-one and its precursors in the brain, plasma, and steroidogenic glands of male and female rats. Endocrinology 133:1003-1009.

Corpechot C, Collins BE, Carey MP, Tsouros A, Robel P, Fry JP (1997) Brain neurosteroids during the mouse oestrous cycle. Brain Res 766:276-280.

Criswell HE, Simson PE, Duncan GE, McCown TJ, Herbert JS, Morrow AL, Breese GR (1993) Molecular basis for regionally specific action of ethanol on gamma-aminobutyric acid A receptors: generalization to other ligand-gated ion channels. J Pharmacol Exp Ther 267:522-537.

Dayanithi G, Tapia-Arancibia L (1996) Rise in intracellular calcium via a nongenomic effect of allopregnanolone in fetal rat hypothalamic neurons. J Neurosci 16:130-136.

Dunn E, Fritschy JM, Carter DB, Merchant KM (1996) Differential distribution of gamma-aminobutyric acid A receptor subunit (alpha 1, alpha 2, alpha 3 , alpha 5 and beta $2+3$ ) immunoreactivity in the medial prefrontal cortex of the rat. Neurosci Lett 210:213-217.

Dunne EL, Moss SJ, Smart TG (1998) Inhibition of GABA receptor function by tyrosine kinase inhibitors and their inactive analogues. Mol Cell Neurosci 12:300-310.

Fenelon VS, Herbison AE (1995) Characterisation of GABA receptor gamma subunit expression by magnocellular neurones in rat hypothalamus. Brain Res Mol Brain Res 34:45-56.

Fenelon VS, Herbison AE (1996) Plasticity in $\mathrm{GABA}_{\mathrm{A}}$ receptor subunit mRNA expression by hypothalamic magnocellular neurons in the adult rat. J Neurosci 16:4872-4880.

Fenelon VS, Sieghart W, Herbison AE (1995) Cellular localization and differential distribution of $\mathrm{GABA}_{\mathrm{A}}$ receptor subunit proteins and messenger RNAs within hypothalamic magnocellular neurons. Neuroscience 64:1129-1143.

Genazzani AR, Palumbo MA, de Micheroux AA, Artini PG, Criscuolo M, Ficarra G, Guo AL, Benelli A, Bertolini A, Petraglia F (1995) Evidence for a role for the neurosteroid allopregnanolone in the modulation of reproductive function in female rats. Eur J Endocrinol 133:375-380.

Giustetto M, Kirsch J, Fritschy JM, Cantino D, Sassoe-Pognetto M (1998) Localization of the clustering protein gephyrin at GABAergic synapses in the main olfactory bulb of the rat. J Comp Neurol 395:231-244.

Gyenes M, Farrant M, Farb DH (1994) Phosphorylation factors control neurotransmitter and neuromodulator actions at the gammaaminobutyric acid type A receptor. Mol Pharmacol 46:542-549.

Harrison NL, Majewska MD, Harrington JW, Barker JL (1987) Structure-activity relationships for steroid interaction with the gammaaminobutyric acid A receptor complex. J Pharmacol Exp Ther 241:346-353.

Hawkinson JE, Kimbrough CL, McCauley LD, Bolger MB, Lan NC, Gee KW (1994) The neuroactive steroid $3 \alpha$-hydroxy- $5 \beta$-pregnan-20-one is a two-component modulator of ligand binding to the $\mathrm{GABA}_{\mathrm{A}}$ receptor. Eur J Pharmacol 269:157-163.

Heesch CM, Rogers RC (1995) Effects of pregnancy and progesterone metabolites on regulation of sympathetic outflow. Clin Exp Pharmacol Physiol 22:136-142.

Huntsman MM, Leggio MG, Jones EG (1996) Nucleus-specific expression of GABA(A) receptor subunit mRNAs in monkey thalamus. J Neurosci 16:3571-3589.

Inglefield JR, Sieghart W, Kellogg CK (1994) Immunohistochemical and neurochemical evidence for $\mathrm{GABA}_{\mathrm{A}}$ receptor heterogeneity between the hypothalamus and cortex. J Chem Neuroanat 7:243-252.

Jones MV, Westbrook GL (1995) Desensitized states prolong GABA $_{\mathrm{A}}$ channel responses to brief agonist pulses. Neuron 15:181-191.

Jones MV, Westbrook GL (1997) Shaping of IPSCs by endogenous calcineurin activity. J Neurosci 17:7626-7633.

Kellenberger S, Malherbe P, Sigel E (1992) Function of the alpha 1 beta 2 gamma $2 \mathrm{~S}$ gamma-aminobutyric acid type A receptor is modulated by protein kinase $\mathrm{C}$ via multiple phosphorylation sites. J Biol Chem 267:25660-25663.

Krishek BJ, Xie X, Blackstone CD, Huganir RL, Moss SJ, Smart TG (1994) Regulation of $\mathrm{GABA}_{\mathrm{A}}$ receptor function by protein kinase $\mathrm{C}$ phosphorylation. Neuron 12:1081-1095.

Lambert JJ, Peters JA, Sturgess NC, Hales TG (1990) Steroid modulation of the $\mathrm{GABA}_{\mathrm{A}}$ receptor complex: electrophysiological studies. Ciba Found Symp 153:56-71.

Lambert JJ, Belelli D, Hill-Venning C, Peters JA (1995) Neurosteroids and $\mathrm{GABA}_{\mathrm{A}}$ receptor function. Trends Pharmacol Sci 16:295-303.

Le Foll F, Louiset E, Castel H, Vaudry H, Cazin L (1997) Electrophysiological effects of various neuroactive steroids on the GABA(A) receptor in pituitary melanotrope cells. Eur J Pharmacol 331:303-311.

Leidenheimer NJ, Chapell R (1997) Effects of PKC activation and receptor desensitization on neurosteroid modulation of GABA(A) receptors. Brain Res Mol Brain Res 52:173-181.

Lin YF, Angelotti TP, Dudek EM, Browning MD, Macdonald RL (1996) Enhancement of recombinant alpha 1 beta 1 gamma $2 \mathrm{~L}$ gamma- aminobutyric acid A receptor whole-cell currents by protein kinase $\mathrm{C}$ is mediated through phosphorylation of both beta 1 and gamma $2 \mathrm{~L}$ subunits. Mol Pharmacol 50:185-195.

Maitra R, Reynolds JN (1998) Modulation of GABA(A) receptor function by neuroactive steroids: evidence for heterogeneity of steroid sensitivity of recombinant GABA(A) receptor isoforms. Can J Physiol Pharmacol 76:909-920.

Maitra R, Reynolds JN (1999) Subunit dependent modulation of $\mathrm{GABA}_{\mathrm{A}}$ receptor function by neuroactive steroids. Brain Res 819:75-82.

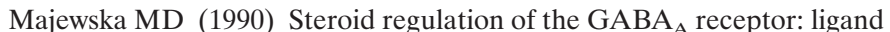
binding, chloride transport and behaviour. Ciba Found Symp 153:83-97.

Majewska MD, Harrison NL, Schwartz RD, Barker JL, Paul SM (1986) Steroid hormone metabolites are barbiturate-like modulators of the GABA receptor. Science 232:1004-1007.

Marty A, Neher E (1983) Tight-seal whole-cell recording. In: Singlechannel recording (Sakmann B, Neher E, eds), pp 107-132. New York: Plenum.

McDonald BJ, Moss SJ (1994) Differential phosphorylation of intracellular domains of gamma-aminobutyric acid type A receptor subunits by calcium/calmodulin type 2-dependent protein kinase and cGMPdependent protein kinase. J Biol Chem 269:18111-18117.

Mize RR, Butler GD (1997) The distribution of the GABA(A) beta2,beta3 subunit receptor in the cat superior colliculus using antibody immunocytochemistry. Neuroscience 79:1121-1135.

Moss SJ, Doherty CA, Huganir RL (1992) Identification of the cAMPdependent protein kinase and protein kinase $\mathrm{C}$ phosphorylation sites within the major intracellular domains of the beta 1 , gamma $2 \mathrm{~S}$, and 
gamma 2L subunits of the gamma-aminobutyric acid type A receptor. J Biol Chem 267:14470-14476.

Moss SJ, Gorrie GH, Amato A, Smart TG (1995) Modulation of GABA $_{A}$ receptors by tyrosine phosphorylation. Nature 377:344-348.

Palumbo MA, Salvestroni C, Gallo R, Guo AL, Genazzani AD, Artini PG, Petraglia F, Genazzani AR (1995) Allopregnanolone concentration in hippocampus of prepubertal rats and female rats throughout estrous cycle. J Endocrinol Invest 18:853-856.

Patchev VK, Hassan AH, Holsboer DF, Almeida OF (1996) The neurosteroid tetrahydroprogesterone attenuates the endocrine response to stress and exerts glucocorticoid-like effects on vasopressin gene transcription in the rat hypothalamus. Neuropsychopharmacology 15:533-540.

Peters JA, Kirkness EF, Callachan H, Lambert JJ, Turner AJ (1988) Modulation of the $\mathrm{GABA}_{\mathrm{A}}$ receptor by depressant barbiturates and pregnane steroids. Br J Pharmacol 94:1257-1269.

Poisbeau P, Feltz P, Schlichter R (1997) Modulation of $\mathrm{GABA}_{\mathrm{A}}$ receptor-mediated IPSCs by neuroactive steroids in a rat hypothalamohypophyseal coculture model. J Physiol (Lond) 500:475-485.

Poisbeau P, Cheney MC, Browning MD, Mody I (1999) Modulation of synaptic $\mathrm{GABA}_{\mathrm{A}}$ receptor function by PKA and PKC in adult hippocampal neurons. J Neurosci 19:674-683.

Puia G, Santi MR, Vicini S, Pritchett DB, Purdy RH, Paul SM, Seeburg PH, Costa E (1990) Neurosteroids act on recombinant human $\mathrm{GABA}_{\mathrm{A}}$ receptors. Neuron 4:759-765.

Puia G, Ducic I, Vicini S, Costa E (1993) Does neurosteroid modulatory efficacy depend on $\mathrm{GABA}_{\mathrm{A}}$ receptor subunit composition? Receptors Channels 1:135-142.

Purdy RH, Morrow AL, Moore Jr PH, Paul SM (1991) Stress-induced elevations of gamma-aminobutyric acid type A receptor-active steroids in the rat brain. Proc Natl Acad Sci USA 88:4553-4557.

Reith CA, Sillar KT (1997) Pre- and postsynaptic modulation of spinal GABAergic neurotransmission by the neurosteroid, 5 beta-pregnan-3 alpha-ol-20-one. Brain Res 770:202-212.

Richardson CM, Wakerley JB (1998) Supraoptic oxytocin and vasopressin neurones show differential sensitivity to the neurosteroid pregnenolone sulphate. J Neuroendocrinol 10:829-837.

Rick CE, Ye Q, Finn SE, Harrison NL (1998) Neurosteroids act on the GABA(A) receptor at sites on the N-terminal side of the middle of TM2. NeuroReport 9:379-383.
Rupprecht R, Reul JM, Trapp T, van Steensel B, Wetzel C, Damm K, Zieglgansberger W, Holsboer F (1993) Progesterone receptormediated effects of neuroactive steroids. Neuron 11:523-530.

Schumacher M, Baulieu EE (1995) Neurosteroids: synthesis and functions in the central and peripheral nervous systems. Ciba Found Symp 191:90-106.

Shingai R, Sutherland ML, Barnard EA (1991) Effects of subunit types of the cloned $\mathrm{GABA}_{\mathrm{A}}$ receptor on the response to a neurosteroid. Eur J Pharmacol 206:77-80.

Smith SS, Gong QH, Hsu FC, Markowitz RS, ffrench-Mullen JM, Li X (1998) GABA(A) receptor alpha4 subunit suppression prevents withdrawal properties of an endogenous steroid. Nature 392:926-930.

Sweetnam PM, Lloyd J, Gallombardo P, Malison RT, Gallager DW, Tallman JF, Nestler EJ (1988) Phosphorylation of the GABA $/$ /benzodiazepine receptor alpha subunit by a receptor-associated protein kinase. J Neurochem 51:1274-1284.

Twyman RE, Macdonald RL (1992) Neurosteroid regulation of $\mathrm{GABA}_{\mathrm{A}}$ receptor single-channel kinetic properties of mouse spinal cord neurons in culture. J Physiol (Lond) 456:215-245.

Wang H, Bedford FK, Brandon NJ, Moss SJ, Olsen RW (1999) GABA(A)-receptor-associated protein links GABA(A) receptors and the cytoskeleton. Nature 397:69-72.

Yang SH, Armson PF, Cha J, Phillips WD (1997) Clustering of GABA receptors by rapsyn $/ 43 \mathrm{kD}$ protein in vitro. Mol Cell Neurosci $8: 430-438$.

Zaman SH, Shingai R, Harvey RJ, Darlison MG, Barnard EA (1992) Effects of subunit types of the recombinant $\mathrm{GABA}_{\mathrm{A}}$ receptor on the response to a neurosteroid. Eur J Pharmacol 225:321-330.

Zhang JH, Sato M, Tohyama M (1991) Region-specific expression of the mRNAs encoding beta subunits (beta 1, beta 2, and beta 3 ) of GABAA receptor in the rat brain. J Comp Neurol 303:637-657.

Zhang SJ, Jackson MB (1994) Neuroactive steroids modulate GABA $_{\mathrm{A}}$ receptors in peptidergic nerve terminals. J Neuroendocrinol 6:533-538.

Zhu WJ, Vicini S (1997) Neurosteroid prolongs GABA $_{\mathrm{A}}$ channel deactivation by altering kinetics of desensitized states. J Neurosci 17:4022-4031.

Zhu WJ, Wang JF, Krueger KE, Vicini S (1996) Delta subunit inhibits neurosteroid modulation of $\mathrm{GABA}_{\mathrm{A}}$ receptors. J Neurosci 16:66486656. 